\title{
Academic Aeromobility in the Global Periphery
}

\author{
James Higham, Debbie Hopkins, \\ and Caroline Orchiston
}

\section{Introduction}

Aeromobility - the 'dominance of flying as the normal international mode of travelling' (Adey et al., 2007: 774) — is an important cause of global social and environmental injustice (Anderson \& Bows, 2008; Urry, 2010). This has become even more apparent in light of research suggesting that just 1 per cent of the world's population emits 50 per cent of $\mathrm{CO}_{2}$ from commercial aviation (Gössling \& Humpe, 2020). It has long been established that academics fall into this tiny minority of very high emitters (Høyer \& Næss, 2001). Moreover, as a rule, systems of academia have been slow to respond, despite the fact that academic air travel-related emissions have become increasingly difficult to ignore

J. Higham $(\bowtie) \bullet$ C. Orchiston

University of Otago, Dunedin, New Zealand

e-mail: james.higham@otago.ac.nz; caroline.orchiston@otago.ac.nz

D. Hopkins

University of Oxford, Oxford, UK

e-mail: debbie.hopkins@ouce.ox.ac.uk 
(Lassen et al., 2009; Caset et al., 2018). Ironically, climate scientists have been shown to fly for work more than other researchers, even when flying for fieldwork is accounted for (Whitmarsh et al., 2020). It is widely recognised and accepted that the complexities of academic air travel practices must be situated within the social and material basis of work travel, in specific geographical and institutional contexts (Lassen et al., 2009; Storme et al., 2017). Within this context, our aim in this chapter focus falls upon academic aeromobility in the global periphery.

Our research programme has addressed the work-sociology of academic aeromobility at the University of Otago (Aotearoa/New Zealand) in order to achieve insights into the air travel practices of academics working in a geographically distant institutional setting. In this chapter, we present the findings of a programme of interviews conducted with academics working in a range of disciplines at the University of Otago. Our interviews investigated climate change concerns and air travel practices as shaped and influenced by employer expectations, institutional policies, disciplinary standards and norms as well as personal and professional circumstances. Our investigation of contextually subjective views on academic aeromobility practices extended to consideration of individual and institutional climate accountability and the potential for virtual mobility substitution to reduce the need for recurrent academic air travel. The research that we report upon in this chapter was conducted prior to the COVID-19 pandemic, which has imposed extraordinary constraints on academic air travel and offered insights into the potential for new academic practices to emerge. In the latter part of this chapter, we pay particular attention to the 2020 COVID-19 disruption and the implications of the pandemic for a fundamental shift in the long-standing aeromobility practices of the global academic community.

\section{Aeromobility in the Global Academic Periphery}

Responding to aviation's high emissions requires urgent action specifically addressing the most frequent of fliers (Schiller \& Revilla Diez, 2012; Gössling \& Humpe, 2020), a category referred to as the 'high emitters' (Anderson \& Bows, 2008). This category includes academics—and 
particularly those who are employed at geographically distant academic institutions. Few academic institutions in the global periphery are more geographically distant than the University of Otago, the main campus of which is located in the city of Otepoti (Dunedin) in the deep south of Aotearoa (New Zealand). The University of Otago has made anecdotal claim to being the most geographically isolated internationally ranked university in the world. Prior to the COVID-19 global pandemic, University of Otago academic staff were highly dependent on recurrent long-haul air travel (Hopkins et al., 2016). This has come to be seen as inconsistent with the university's Sustainability Charter, its role as the 'critic and conscience of society' (New Zealand Education Act 1989; see also Stohl, 2008) and its commitment to global citizenship (Hopkins et al., 2016).

Like many other leading tertiary institutions around the world, the University of Otago has embarked on an internationalisation pathway (Storme et al., 2017) which can be seen as a key driver of increasingly entrenched academic aeromobility. At the University of Otago, internationalisation is built through the recruitment of international academic staff and graduate students, publication in international journals, high visibility at international conferences and meetings, international collaborations and invitations to deliver presentations to international audiences (University of Otago, 2013). Tenure (confirmation), performance review, promotion and research assessments ${ }^{1}$ are significantly influenced by these aspects of an academic's career. Internationalisation may also be pursued through the recruitment of international undergraduate students, curriculum development and student exchange programmes (University of Otago, 2013).

For geographically distanced institutions, support for the development and maintenance of international collaborations is even more important for the recruitment and retention of academic staff. Given the high proportion of international staff at the University of Otago-with family, friends and colleagues in far-flung parts of the world-frequent travel is important for both personal and professional reasons. Internationalisation, therefore, comes with associated academic mobility practices that are closely tied to both personal and professional interests (Hoffman, 2009; Cohen et al., 2015). Academic aeromobility practices are at least in part driven by the need to remain connected to distant family, as well as 
retaining networks developed through (multiple) postdoctoral positions around the world (Hopkins et al., 2019).

Storme et al. note 'empirical studies that explore what compels and motivates academics to travel are very rare, especially in terms of analysis of the complex interplay between corporeal (physical) and virtual mobility' (Storme et al., 2017: 406). While there is a burgeoning body of scholarship, most studies to date have tended to address academic mobility practices in the Global North, with a particular bias towards EuroAmerican institutions (Ackers, 2008; Lassen, 2006; Leung, 2013; Storme et al., 2013; Storme et al., 2017). Situated in the context of a globally distant institution, our research has explored the drivers of academic aeromobility in the global periphery (Higham et al., 2019). This focus offers unique insights into the institutional policies and academic mobilities of globally distant institutions as they seek to replicate the mobility practices of academics based in 'academic centres' of Europe and North America (Hopkins et al., 2019) and relate to sustainability objectives (Hopkins et al., 2016; University of Otago Sustainability Framework 2017-2021, 2017).

\section{Empirical Materials}

Our research investigated the aeromobility practices of academic staff at the University of Otago (Higham et al., 2019). We designed and implemented a programme of interviews with academic staff employed in a range of disciplinary fields to investigate contextually subjective views on climate change and academic aeromobility. We designed an interview schedule to explore aeromobility practices in relation to institutional expectations, disciplinary standards and norms as well as personal and professional circumstances. Questions of climate accountability and virtual mobility substitution were relevant to all of our interviews. Our interviews were semi-structured, allowing interview participants to explore avenues of conversation that were not driven by the interview schedule (Jennings, 2001; Fontana \& Frey, 2005). It is important to note that the data collection phase predated the COVID-19 pandemic. 
Interview participants were recruited from randomly sampled departments in all four of the university's academic divisions (Commerce, Health Sciences, Humanities and Sciences) (see Table 8.1). Academic staff from the sampled department were then recruited using a random number function. Our sample of participants was stratified to ensure representation on the basis of gender and levels of the academic scale. Thus, the interviewees who participated in our study were representative of gender, age and junior/senior academic staff status.

A total of 31 interviews were conducted with academic staff in three Commerce departments (Economics, Accountancy and Finance and Marketing), three Humanities departments (Music, Classics and Philosophy), five Sciences departments (Chemistry, Physics, Surveying, Zoology and Physical Education, Sport and Exercise Sciences) and three Health Science departments (Microbiology, Obstetrics \& Gynaecology and Anatomy). Interview participants included 21 male and 10 female staff and a balance of academic positions (8 Professors; 8 Associate Professors; 7 Senior Lecturers; 5 Lecturers; 2 Senior Research Fellows; 1 Postdoctoral Fellow). Interviews were fully transcribed and then subject to a blind process of analysis by members of the research team before individual interpretations were drawn together and subjected to a manual thematic analysis that was conducted interactively (Patton, 2002). In this collaborative phase, the empirical material was reduced into broad categories, and emergent themes were identified (Miles \& Huberman, 1994; O’Reilly, 2005). Contrasting interpretations were discussed collectively to allow us to arrive at congruent interpretations of the empirical material (Patton, 2002). Four themes emerged from our analysis. Verbatim interview quotes were referenced by codes that explain the interview number (\#), academic division (Com/HS/Hum/Sci), gender (M/F) and level of appointment (junior/senior) of the interview participant (see Table 8.1). 
Table 8.1 Summary of interview participants. (Source: Higham et al., 2019)

\begin{tabular}{|c|c|c|c|c|}
\hline $\begin{array}{l}\text { Interview } \\
\text { code* }\end{array}$ & Division & Gender & Academic position & $\begin{array}{l}\text { Interview } \\
\text { length } \\
\text { (minutes) }\end{array}$ \\
\hline$\# 1 / \mathrm{Com} / \mathrm{M} / \mathrm{S}$ & Commerce & Male & Associate Professor & 34 \\
\hline \#2/Com/F/J & Commerce & Female & Lecturer & 32 \\
\hline \#3/Com/M/J & Commerce & Male & Senior Lecturer & 34 \\
\hline \#4/Com/F/J & Commerce & Female & Senior Lecturer & 39 \\
\hline \#5/Com/M/s & Commerce & Male & Associate Professor & 47 \\
\hline \#6/Com/M/S & Commerce & Male & Associate Professor & 49 \\
\hline$\# 7 / \mathrm{Com} / \mathrm{M} / \mathrm{s}$ & Commerce & Male & Professor & 59 \\
\hline \#8/Hum/M/S & Humanities & Male & Professor & 54 \\
\hline \#9/Hum/F/S & Humanities & Female & Associate Professor & 43 \\
\hline \#10/Hum/M/J & Humanities & Male & Senior Lecturer & 52 \\
\hline \#11/Hum/M/J & Humanities & Male & Lecturer & 44 \\
\hline \#12/Hum/M/S & Humanities & Male & Professor & 59 \\
\hline \#13/Hum/F/S & Humanities & Female & Associate Professor & 47 \\
\hline \#14/Hum/M/S & Humanities & Male & Professor & 41 \\
\hline \#15/Hum/M/S & Humanities & Male & Associate Professor & 36 \\
\hline$\# 16 / \mathrm{Sci} / \mathrm{M} / \mathrm{J}$ & Sciences & Male & Lecturer & 22 \\
\hline$\# 17 / \mathrm{Sci} / \mathrm{M} / \mathrm{J}$ & Sciences & Male & Postdoctoral Fellow & 50 \\
\hline \#18/Sci/M/S & Sciences & Male & Professor & 54 \\
\hline \#19/Sci/M/J & Sciences & Male & Lecturer & 45 \\
\hline$\# 20 / S c i / F / S$ & Sciences & Female & Associate Professor & 36 \\
\hline \#21/Sci/F/J & Sciences & Female & Senior Lecturer & 42 \\
\hline \#22/Sci/M/J & Sciences & Male & Lecturer & 36 \\
\hline \#23/Sci/F/S & Sciences & Female & Professor & 47 \\
\hline$\# 24 / \mathrm{HS} / \mathrm{M} / \mathrm{S}$ & $\begin{array}{l}\text { Health } \\
\text { Sciences }\end{array}$ & Male & Professor & 42 \\
\hline \#25/HS/M/S & $\begin{array}{l}\text { Health } \\
\text { Sciences }\end{array}$ & Male & Associate Professor & 29 \\
\hline \#26/HS/F/J & $\begin{array}{l}\text { Health } \\
\text { Sciences }\end{array}$ & Female & Senior Lecturer & 44 \\
\hline$\# 27 / \mathrm{HS} / \mathrm{F} / \mathrm{J}$ & $\begin{array}{l}\text { Health } \\
\text { Sciences }\end{array}$ & Female & Senior Lecturer & 48 \\
\hline \#28/HS/M/S & $\begin{array}{l}\text { Health } \\
\text { Sciences }\end{array}$ & Male & Professor & 42 \\
\hline \#29/HS/F/J & $\begin{array}{l}\text { Health } \\
\text { Sciences }\end{array}$ & Female & $\begin{array}{l}\text { Senior Research } \\
\text { Fellow }\end{array}$ & 33 \\
\hline$\# 30 / \mathrm{HS} / \mathrm{M} / \mathrm{J}$ & $\begin{array}{l}\text { Health } \\
\text { Sciences }\end{array}$ & Male & $\begin{array}{l}\text { Senior Research } \\
\text { Fellow }\end{array}$ & 35 \\
\hline$\# 31 / \mathrm{HS} / \mathrm{M} / \mathrm{J}$ & $\begin{array}{l}\text { Health } \\
\text { Sciences }\end{array}$ & Male & Lecturer & 42 \\
\hline
\end{tabular}


Table 8.1 (continued)

Notes: *The University of Otago departments are organised into four divisions. Com $=$ Commerce,

Hum = Humanities, Sci $=$ Sciences, HS = Health Sciences; $\mathrm{S}$ denotes senior academic positions: Professor $(n=8)$ and Associate Professor $(n=8)$; J denotes junior academic positions: Senior Lecturer $(n=7)$, Lecturer $(n=5)$, Senior Research Fellow $(n=2)$, Postdoctoral Fellow $(n=1)$.

\section{Results}

\section{Complex Drivers}

Our programme of interviews revealed complex drivers of academic travel practices, which were influenced by combinations of professional (institutional, disciplinary, academic associations), social and personal factors. Academic mobility practices are subject to a range of informal and tacit work practices that have traditionally required corporeal proximity (Storme et al., 2013). The drivers of corporeal mobility vary between disciplines and between individuals who articulated a wide range of personal drivers. Some disciplines require travel due to the demands of field or laboratory-based research (see Heffernan \& Jons, 2013). Some researchers in the science disciplines considered themselves to be locked into 'super mobile' professions (Lassen, 2006). By contrast, other disciplines have experienced a revolution of archival digitisation. While the need to travel to visit archives was still considered necessary by some, others felt quite able to use digital archives for their research. ' 30 years ago you would have had to travel outside of New Zealand.... The French National Library have a lot of $17^{\text {th }}$ century texts in PDF format. Not only can you view them, you can download them' (\#15/Hum/M/S). Similar views were evident among researchers in the Commerce disciplines of Economics; Accountancy and Finance. 'I can access databases ... from my office so I don't need direct contact with people other than co-authors' (\#2/Com/F/J).

Among the complex drivers of academic aeromobility at the University of Otago, it was clear that a heavy 'mobility burden' (Urry, 2003) is an inescapable reality of being located at a remote institution. This burden 
arises from the need to build or maintain network capital (Storme et al., 2013). Networks are generally considered to be fundamental to a successful academic career. 'It [travel] is really, really important because you need to have a profile. Without a profile you're not going to get grants. You're not going to keep up with the current state of play' (\#16/Sci/M/J). The importance of academic network capital was widely expressed amongst our sample. Furthermore, researchers in the humanities-which are likely to be replicated across multiple disciplines - expressed a blurring of academic and social networks (Urry, 2003), in relation to 'living' their research: 'I've got to travel to ... speak to culture bearers, cultural informants, collaborators, insiders ... you need to be there and observe and participate' (\#8/Hum/M/S). Thus for particular types of research 'being there' has the necessity for corporeal mobility.

The high 'mobility burden' associated with working at a remote institution was associated with a risk of academics becoming 'off-balance' in their aeromobilities. This is a term used by Storme et al. (2013) to describe academics who travel beyond reasonable limits. Remaining connected with distant family was a social driver of academic travel (see also Hopkins et al., 2019). Choice of conference was often influenced by personal drivers, such as visiting distant family members. Equally, domestic commitments emerged as a barrier to travel. 'When I went to the UK it was ... hard [for my wife] because we're relatively new to New Zealand; we don't have a family support network' (\#3/Com/M/J). The challenges that academics at remote institutions experience in both managing the 'mobility burden' that they face and maintaining 'balance' in their professional and personal lives were clearly expressed in this theme.

\section{Selective Substitution}

Our interview programme was intended to achieve insights into the much talked about but largely unfulfilled scope for virtual mobility substitution (Hopkins et al., 2016; Storme et al., 2017). The interviews revealed that virtual substitution was seen to be a reasonable alternative to physical travel in many instances, but was highly selective in practice. Decisions on substituting air travel for virtual attendance were informed 
by personal assessments of importance, efficiency and effectiveness. It clearly emerged that virtual mobility substitution is seen to be inferior to physical attendance, and therefore predominantly a substitute for nonparticipation. Virtual participation was considered to be less effective than physical participation (Urry, 2003), but growing in potential and worthy of active encouragement. 'Skype is a bit like watching a YouTube recording of something, it's never quite the same ... but if the alternative is non-participation then I think it's worth looking at, definitely' (\#11/ Hum/M/J).

Colleagues generally agreed that virtual meetings were effective in instances such as convening a $\mathrm{PhD}$ viva and in building upon existing networks and collaborations. However, virtual substitution was generally viewed as inadequate in facilitating participation in building networks. Face-to-face interaction and engagement within professional and social networks were considered irreplaceable (Urry, 2003): 'Meeting face to face and socialising; there is no substitute for that....There are some of those people that I have met at crucial times who for one reason or another you've struck a rapport with and they've been instrumental in getting my career going' (\#12/Hum/M/S). Physical co-presence was viewed to be beyond substitution in terms of networks and relationships, with virtual meetings being ineffective in reproducing the all-important human dimensions of personal interaction: 'I have been to a couple of meetings where they've video linked in somebody who couldn't be in town; and there's always the feeling that that person is kind of separate from the group-it's just never quite as inclusive' (\#4/Com/F/J). The physical aspects of being co-present are considered fundamental to building trust (Urry, 2003), yet at a geographically remote institution this then depends on (extreme) long-haul travel, often for short durations (see, e.g., Hopkins et al., 2019).

\section{'Don't weaken me!'}

The third theme that emerged from our analysis was bluntly expressed by one of the interview participants (\#13/Hum/F/S). She explained that excluding oneself from the very system that underpins our 
institutions - in this case, the carbon-dependent aviation socio-technical regime_-will only result in professional disempowerment.

I don't limit my travel because I have a strong belief that the individualisation of risk is a strategy that disempowers people who would otherwise be powerful and affect change. I think if individuals view it as an individual decision ... they're making a serious mistake and they're participating in a hegemonic viewpoint that nobody intends. They undermine their own agency by participating in that viewpoint. ... I certainly should try harder to live ecologically. I make some choices that are good and many that are less good but I don't think my first step should be to make myself weaker. (\#13/Hum/F/S)

The position articulated here is an important one; what role does the individual play in the structural issue of carbon dependency? The role of academic institutions as the 'critic and conscience of society' (New Zealand Education Act 1989) was considered particularly important in times of urgent transition (Young et al., 2015). Within this context, some felt that academics need to be at the forefront of solving difficult problems facing society. This means continuing to fly for academic purposes, rather than reducing an individual academic's own agency in order to achieve an insignificant reduction in carbon emissions. This participant reflects on the individual damage that would be done by restricting their mobilities, which helps to reinforce the embeddedness of mobility to academic practice. This lock-in to high-carbon behaviour has been well documented with relation to automobility, and this is pointing to its important role here too. This may suggest that other actors-academic institutions, networks of institutions, disciplinary bodies and so onmust take leadership roles to dismantle the structures of carbon dependency.

Aeromobility practices were also linked to career security and trajectories. Our interview programme gave voice to the view that reducing or limiting air travel is unacceptable in terms of compromising academic careers. "If you said, "Okay I'm not going to fly anywhere" I would have stayed as a senior lecturer for the rest of my life-waiting to be performance managed out of the university for failing to do my job as they see 
it' (\#6/Com/M/S). The importance of academic network sociality (Urry, 2003) again emerged, highlighting the importance of strong academic networks as 'absolutely instrumental' and 'without substitute' (\#12/ Hum/M/S). 'If you want to publish in the top journals, you need to be at these top conferences networking. If the editors have met you, you know it just makes a difference' $(\# 3 / \mathrm{Com} / \mathrm{M} / \mathrm{J})$. While the relationship between mobility and career progression has been explored in the published literature (Storme et al., 2017), it is interesting to note that a recent study of academic air travel among scholars at the University of British Columbia found that aeromobility has a very limited impact on professional success (Wynes et al., 2019). That said, networking was considered critical to academics working at a remote institution, casting doubt upon the potential for virtual substitution.

\section{Assorted Scalar Accountabilities}

The final theme to emerge from our analysis builds upon the individualised impacts of not flying, or 'flyingless' articulated in the previous theme and relates to the need for accountability and action across a range of scales. At the scale of the individual (academic), some argued that 'There is very little that I can do about that given that we are a very long way away from the rest of the world. I don't think there are any alternatives; we have got to use air travel' (\#19/Sci/M/J). Others recognised much scope for individuals to significantly reduce their personal aeromobilities. However, climate concern was very rarely a driver of individual air travel decisions, for example, one participant noted how 'It would be really nice to think about decisions as being environmentally sustainable but it wouldn't be true to say that's what's driving my decision-making' (\#13/ Hum/F/S). The benefits of having strong personal and professional global academic networks run counter to the need to reduce air travel. This extensive quote was typical of a widespread view:

Carbon costs are imposed by deciding to live in New Zealand and pursue an academic career. ... We are quite conscious consumers in other parts of our lives ... but there is no way around travelling. It's necessary if you want 
to become a professor [and] it's necessary if you want to maintain your relationship with your partner, your relatives and your friends. Necessary is a word that can hide all manner of sins. One could argue that none of those things are necessary but if you accept that those things are important then they are necessary. (\#6/Com/M/S)

Beyond the individual, some argued that the University of Otago should extend its current local emissions mitigation efforts to include air travel. Offsetting and fossil fuel divestment were considered necessary actions. So, too, was an institutional response to encourage and empower individual academics to consider environmental concerns in travel decisions, and to ensure that changes in academic travel practices can occur without personal or professional disadvantage, for instance, 'If you had a programme that rewarded people who are able to make reductions in anticipated non-zero emissions; that could be pretty neat' (\#13/Hum/F/S). Many participants expressed the strong view that changes in air travel decision-making should be autonomous rather than imposed (Tindall Travel Strategy 2015) and that institutional change must ensure that virtual mobility substitution is encouraged without individual disadvantage (Hopkins et al., 2016). Addressing the structural and institutional constraints that underpin academic mobility practices (Parker \& Weik, 2014) should include a commitment to invest in the technologies that will continue to redefine the possibilities for virtual mobility substitution.

Finally, within this theme, at the global scale of collective action, it was considered most necessary that scientific communities, and academic associations (and their conference programmes), reaching across universities, also play a critical part. Specifically, in a collective society if we agreed, okay well let's not hold this conference, let's all meet online ... and improve our connectivity ... that would be a good way to go' (\#28/ $\mathrm{HS} / \mathrm{M} / \mathrm{S})$. The need to move from a focus on individual decision-making to collective action as expressed through institutional policy settings, and coordinated regional/global efforts to reduce academic aeromobilities, was an important point that emerged in our analysis. 


\section{The COVID-19 Acceleration}

Of course, these findings predate the COVID-19 global pandemic. The pandemic forced an immediate response from conference committees; some were immediately cancelled, others were postponed, some were moved fully or partially online. In doing so, the pandemic opened a window of opportunity to reflect upon the long unquestioned necessity of academic conference travel. Interestingly, when the European Geosciences Union (EGU) meeting in May 2020 moved online, the number of delegates increased from 16,000 to 22,000 , with new attendees from 28 previously unrepresented countries. This has drawn attention to the long-standing inequities and privileges of academic conferences, and the barriers to participation that had been ignored prior to the pandemic.

Insights into pre-and post-COVID conference regimes have been explored in a research collaboration at the University of Oxford led by Milan Klöwer (Klöwer et al., 2020). The research analysed the transportrelated emissions of conference delegates of the Fall 2019 Meeting of the American Geophysical Union (AGU), the world's largest annual geosciences conference. The 2019 AGU was hosted in San Francisco, with 24,008 presenters and 28,000 attendees. The analysis conducted by Klöwer et al. (2020) highlighted the air travel dependence of the preCOVID- global academic conference regime. One-third of the delegates (approximately 10,000 participants) were found to be accountable for three-quarters of total AGU 2019 transport emissions. These delegates required intercontinental flights of greater than $8000 \mathrm{~km}$, with the highest-emitting delegates travelling from India, Australia, New Zealand, China and Taiwan (Klöwer et al., 2020). The research continued by considering the emissions associated with alternative host venues in North America and found that an optimum location-Chicago — could reduce AGU transport emissions by 12.3 per cent, yet Hawaii, for instance, could have increased emissions by 42 per cent (Klöwer et al., 2020). These findings are important insomuch as they show the role that selecting cities for conferences has in effecting the conference's emissions: thus, conference organisers and disciplinary organisations need to be cognisant 
of such decisions, as the AGU is not alone, and many large national disciplinary conferences move city year to year.

From their analysis, Klöwer et al. (2020) highlight three important measures required to meaningfully address the carbon footprint of major international conferences:

\section{1. choosing accessible venues;}

2. increasing virtual attendance and

3. switching to biennial conferences

The analysis found that, in combination, these three measures could reduce travel-related carbon emissions of the AGU by 91 per cent. However, such decisions cannot be taken lightly; there is a politics to these decisions, as requiring those who would otherwise travel furthest to attend virtually risks the in-person exclusion of researchers located in the most geographically distant institutions-including the University of Otago.

This highlights the need for a low-carbon, post-COVID conference convention that offers rich new opportunities for the integration of virtual and in-person conference experiences. This could build upon the skills, know-how and technological developments which have occurred rapidly during 2020, as well as introducing what Klöwer et al. (2020) refer to as a 'three hub' conference model. The notion of conferences being hosted in three or more virtually connected conference hubs allows delegates to travel to their nearest hub rather than to a single global conference host city-thus the distance travelled is minimised, while still allowing for co-presence. Conferences would take place simultaneously in multiple hubs locations, with planning required to accommodate global time zones to maximise comfort and minimise inconvenience. Occasional sessions at inconvenient hours in some time zones can be overcome by recording sessions, but otherwise offer less physiological stress than multiple long-haul flights (Cohen \& Gössling, 2015), particularly in light of the bodily effects of long-haul academic travel highlighted by Hopkins et al. (2019), which include jet lag, bodily aches and pains, as well as challenges to mental health and wellbeing. 


\section{Conferences Reimagined: Entrenching a Post-COVID New Normal}

COVID-19 is a global crisis that has drawn existing systems into deep question. Now important questions arise as to what will happen when post-COVID normality is restored. The rapid move to online conferences in response to COVID-19 will not become the new conference convention by default. It is abundantly clear that climate change knowledge on its own will not significantly alter established practices of academic flying. Rather knowledge is a first step towards the structural change required to radically alter flying practices (Whitmarsh et al., 2020). The concerted and coordinated actions of a number of key actors will be required to design and embed a radical new conference convention in pursuit of a low-carbon future (Klöwer et al., 2020).

First and foremost, disciplinary associations and academic bodies must actively advance a new conference convention to reduce the carbon footprint of academic practices, while building virtual networks and inclusivity. The move to biennial conferences with fully virtual meetings in alternate years should be an immediate action. A number of disciplinary associations are now advancing this agenda. A group of Australian environmental historians have recently had a working paper on sustainable disciplinary practices endorsed by the Australian Historical Association, ${ }^{2}$ the Western Political Science Association now has a virtual communities initiative ${ }^{3}$ and a petition was recently circulated among sociologists wanting to address the decarbonisation of the American Sociological Association. ${ }^{4}$ These initiatives are timely, as they challenge us to rethink how scholarly disciplines function.

Decisive institutional action is also required (Whitmarsh et al., 2020). Annual staff conference budgets should be diverted where appropriate to support other low-carbon research activities. Instead of funding conference travel and accommodation by default, the costs of virtual conference attendance should be prioritised given that fully virtual conferences produce approximately 0.01 per cent of the emissions of full attendance conferences (Klöwer et al., 2020). Conference funding policies should be extended or transitioned to include expenses for virtual attendance, and 
there should be mechanisms for requesting conference leave to allow full virtual participation. This might include conference leave approval and 'local' accommodation costs to allow full engagement in virtual conferences. In the case of globally distant institutions, this may require academics to attend sessions at unconventional hours of the day or night. Travel carbon budgets might be implemented on a differential basis based on career stage and other criteria (Cobb et al., 2018).

The material cultures of institutional conference activities should transition through investment in virtual technologies, technical support and conference social media engagement. COVID-19 has shown that such actions can happen with remarkable speed when required, and this knowledge, know-how and capacity could be harnessed to drive forward a radical new conference convention. The move to increasing virtual conference opportunities is critical if globally distant institutions, and individuals working at those institutions, are to reduce their air travel emissions. There is, of course, potential for backlash after a year of online teaching and researching. Furthermore, our research indicates that there will be resistance from those who are wedded to their pre-COVID air travel practices. Resistance may also come from scholars who are not sufficiently comfortable with new technologies, and those who are accustomed to building and maintaining academic networks through regular physical co-presence (Higham et al., 2019). Institutional promotion, confirmation and research assessment policies (among others) will need to be reviewed and revised to reflect the new model. Coordination across institutions would serve to accelerate and cement the new convention.

Beyond academic associations and institutions, there are important roles of other key actors. Research funding bodies should require comprehensive carbon budgets to be included in grant applications, in order to foster reduced research (and researcher) carbon impacts and low-carbon avenues of (preferably open-access) research dissemination. Conference organisers should model delegate travel emission profiles when selecting host cities while creating and connecting conference hubs to overcome the need for long-haul flights. Conference programmes should be developed not only to cater for 'in person' conference participants but also with careful consideration given to accommodating virtual delegates. Furthermore, conference organisers need to fully resource IT support of 
virtual conference participation and innovate with social media platforms to accelerate improved delivery of virtual conference experiences. Perhaps most importantly, a new conference convention must be built upon the commitment of researchers themselves. It is researchers themselves who must support virtual conferences, accept invitations to present papers virtually and role model equitable approaches to the dissemination of knowledge (Ford et al., 2019).

\section{Conclusion}

Air travel is central to the core business of research and teaching institutions, particularly those that face the unique circumstances associated with being globally distant, such as the University of Otago. Academic institutions are 'network driven workplaces' (Wittel, 2001). Being able to engage internationally is important not only to career success but also to the international standing and reputation of institutions. Prior to COVID-19, the air travel practices of academics made a disproportionate contribution to high-growth aviation emissions (Creutzig et al., 2016). The challenges involved in resolving academic air travel emissions are both particularly acute and particularly important in the case of remote institutions. Our research has contributed to the work-sociology of aeromobility, as it relates to the 'exceptional case' (Faulconbridge and Hui 2016) of academic air travel practices in the global periphery (Caset et al., 2018).

It has been noted that the University of Otago, while committed to sustainable practices and global citizenship (University of Otago, 2017), faces an extraordinarily challenging conundrum in seeking to reduce its dependence on regular, high-carbon long-haul air travel (Hopkins et al., 2016) while seeking to advance its standing in the global academic community. Being international at such a geographical distance has created institutional dependencies that are difficult to divert. Ironically, despite the enormous social and economic upheavals and uncertainties of the COVID-19 global pandemic, it is the disruption caused by COVID-19 and the need to build a new normal, globally and regionally, that has opened a pathway forward for academic institutions. Our research has 
paid close attention to the emerging new normal (Klöwer et al., 2020) and the need to develop innovative solutions to avoid returning to a preCOVID status quo. This will require the dedicated and focussed efforts of various actors, including disciplinary associations, institutions, conference associations and their organising committees, research funding bodies and, importantly, the academic community.

Importantly, it will also need to be a systematic and carefully coordinated effort. Only then will the transition towards new academic regimes arise. Our chapter highlights the coordinated, multi-level response that is required to harness the opportunities and benefit from the experiences gained from COVID-19 moment in time, to build a new normal and resists a return to the pre-COVID high-carbon status quo. Collective action will be required to take advantage of the momentum. Individual academics must commit to building new practices of academic knowledge transfer, networking and collaboration within their departments and schools. Disciplinary associations and conference organisers must show leadership in envisioning better ways to meet, share, network and socialise virtually. Institutions must review and revise policies that drive academic air travel practices and commit to ambitious transport emissions mitigation goals. Collective action should extend to institutions working collaboratively rather than competitively. As an example, an international coalition of leading climate research universities recently announced the International Universities Climate Alliance, ${ }^{5}$ issuing the challenge to universities to drive climate solutions and to implement measures to counteract climate change. Such a network of institutions working collaboratively to address the aeromobility practices of academics is required in Australia and New Zealand, given the unique circumstances associated with being globally distant.

The time for radical change is upon us: 'as Covid-19 has taught us, changes to deeply embedded and seemingly intractable practices can happen with remarkable speed' (Klöwer et al., 2020: 359). Prior to COVID-19 academic travel, practices were deeply embedded and resistant to change (Whitmarsh et al., 2020). The timelines of the opportunity that now arises is perhaps best summed up in a tweet that was posted following the publication of Klöwer et al.'s (2020) analysis of ways to decarbonise conference travel after COVID-19: 
Pre-corona-'Virtual does not really work'

During corona-'Wow it brings so many benefits, and yes it works actually, ops!'

Post-corona-'HOW DARE WE to have exchanged in such an unsustainable and non-inclusive way'

Acknowledgements The authors acknowledge the contributions made to the research reported in this chapter by Sarah Tapp (University of Otago, New Zealand), Dr Tara Duncan (Dalarna University, Sweden), Milan Klöwer and Prof. Myles Allen (both University of Oxford, UK).

\section{Notes}

1. All New Zealand tertiary institutions are subject to the Performancebased Research Fund (PBRF) research assessment exercise, which is modelled upon the UK's Research Excellence Framework.

2. https://sustainablehistorywp.wordpress.com/

3. http://www.wpsanet.org/meeting/climate.php

4. https://www.change.org/p/american-sociological-association-councildecarbonize-asa-meetings

5. https://www.universitiesforclimate.org

\section{References}

Adey, P., Budd, L., \& Hubbard, P. (2007). Flying lessons: exploring the social and cultural geographies of global air travel. Progress in Human Geography, 31(6), 773-791. https://doi.org/10.1177/0309132507083508

Ackers, L. (2008). Internationalisation, mobility and metrics: A new form of indirect discrimination? Minerva, 46(4), 411-435. https://doi.org/10.1007/ s11024-008-9110-2

Anderson, K., \& Bows, A. (2008). Reframing the climate change challenge in light of post-2000 emission trends. Philosophical Transactions of the Royal Society of London A: Mathematical, Physical and Engineering Sciences, 366(1882), 3863-3882. https://doi.org/10.1098/rsta.2008.0138 
Caset, F., Boussauw, K., \& Storme, T. (2018). Meet \& fly: Sustainable transport academics and the elephant in the room. Journal of Transport Geography, 70, 64-67. https://doi.org/10.1016/j.jtrangeo.2018.05.020

Cobb, K. M., Kalmus, P., \& Romps, D. M. (2018). AGU should support its members who fly less. Eos, 99. https://doi.org/10.1029/2018EO111475

Cohen, S. A., Duncan, T., \& Thulemark, M. (2015). Lifestyle mobilities: The crossroads of travel, leisure and migration. Mobilities, 10(1), 155-172. https://doi.org/10.1080/17450101.2013.826481

Cohen, S. A., \& Gössling, S. (2015). A darker side of hypermobility. Environment and Planning A: Economy and Space, 47(8), 1661-1679. https://doi.org/ 10.1177/0308518X15597124

Creutzig, F., Fernandez, B., Haberl, H., Khosla, R., Mulugetta, Y., \& Seto, K. C. (2016). Beyond technology: Demand-side solutions for climate change mitigation. Annual Review of Environment and Resources, 41, 173-198. https://doi.org/10.1146/annurev-environ-110615-085428

Fontana, A., \& Frey, J. H. (2005). The interview: From neutral space to political involvement. In N. K. Denzin \& Y. S. Lincoln (Eds.), The Sage Handbook of Qualitative Research. Third Edition (pp. 695-728). Sage Publications.

Ford, H. L., Brick, C., Azmitia, M., Blaufuss, K., \& Dekens, P. (2019). Women from some under-represented minorities are given too few talks at world's largest Earth-science conference. Nature, 576, 32-35.

Gössling, S., \& Humpe, A. (2020). The global scale, distribution and growth of aviation: Implications for climate change. Global Environmental Change, 65, 102194. https://doi.org/10.1016/j.gloenvcha.2020.102194

Heffernan, M., \& Jons, H. (2013). Research travel and disciplinary identities in the University of Cambridge, 1885-1955. British Journal for the History of Science, 46(2), 255-286. https://doi.org/10.1017/S000708741200074X

Higham, J. E. S., Hopkins, D., \& Orchiston, C. (2019). The work-sociology of academic aeromobility at remote institutions: Networks, co-presence and proximity. Mobilities, 14(5), 612-631. https://doi.org/10.1080/17450101.2019. 1589727

Hoffman, D. M. (2009). Changing academic mobility patterns and international migration: What will academic mobility mean in the 21 st century? Journal of Studies in International Education, 13(3), 347-364. https://doi. org/10.1177/1028315308321374

Hopkins, D., Higham, J., Tapp, S., \& Duncan, T. (2016). Academic mobility in the Anthropocene era: A comparative study of university policy at three New Zealand institutions. Journal of Sustainable Tourism, 24(3), 376-397. https:// doi.org/10.1080/09669582.2015.1071383 
Hopkins, D., Higham, J. E. S., Orchiston, C., \& Duncan, T. (2019). Practising academic mobilities: Bodies, networks and institutional rhythms. The Geographical Journal, 185, 472-484. https://doi.org/10.1111/geoj.12301

Høyer, K. G., \& Næss, P. (2001). Conference tourism: A problem for the environment, as well as for research? Journal of Sustainable Tourism, 9(6), 451-470. https://doi.org/10.1080/09669580108667414

Jennings, G. (2001). Tourism research. John Wiley \& Sons.

Klöwer, M., Hopkins, D., Allen, M., \& Higham, J. E. S. (2020). Decarbonising conference travel after COVID-19. Nature, 583, 356-360. https://www. nature.com/articles/d41586-020-02057-2. https://doi.org/10.1038/ d41586-020-02057-2

Lassen, C. (2006). Aeromobility and work. Environment and Planning A, 38(2), 301-312. https://doi.org/10.1068\%2Fa37278

Lassen, C., Smink, C. K., \& Smidt-Jensen, S. (2009). Experience spaces, (aero) mobilities and environmental impacts. European Planning Studies, 17(6), 887-903. https://doi.org/10.1080/09654310902794034

Leung, M. W. (2013). 'Read ten thousand books, walk ten thousand miles': Geographical mobility and capital accumulation among Chinese scholars. Transactions of the Institute of British Geographers, 38(2), 311-324. https:// doi.org/10.1111/j.1475-5661.2012.00526.x

Miles, M. B., \& Huberman, A. M. (1994). Qualitative data analysis: An expanded sourcebook. Sage Publications.

O'Reilly, K. (2005). Ethnographic methods. Routledge.

Parker, M., \& Weik, E. (2014). Free spirits? The academic on the aeroplane. Management Learning, 45(2), 167-181. https://doi.org/10.1177/13505 07612466210

Patton, M. Q. (2002). Qualitative research and evaluation methods. Sage Publications.

Schiller, D., \& Revilla Diez, J. (2012). The impact of academic mobility on the creation of localized intangible assets. Regional Studies, 46(10), 1319-1332. https://doi.org/10.1080/00343404.2011.571241

Stohl, A. (2008). The travel-related carbon dioxide emissions of atmospheric researchers. Atmospheric Chemistry and Physics, 8(21), 6499-6504.

Storme, T., Beaverstock, J. V., Derrudder, B., Faulconbridge, J. R., \& Witlox, F. (2013). How to cope with mobility expectations in academia: Individual travel strategies of tenured academics at Ghent University, Flanders. Research in Transportation Business \& Management, 9, 12-20. https://doi.org/10.1016/j. rtbm.2013.05.004 
Storme, T., Faulconbridge, J. R., Beaverstock, J. V., Derudder, B., \& Witlox, F. (2017). Mobility and professional networks in academia: An exploration of the obligations of presence. Mobilities, 12(3), 405-424. https://doi.org/1 0.1080/17450101.2015.1116884

University of Otago Strategic Direction to 2020. (2013). Retrieved May 10, 2017, from http://www.otago.ac.nz/otago069833.pdf.

University of Otago Sustainability Framework 2017-2021: Bringing Otago's sustainability commitment to life (2017). Retrieved May 10, 2017, from http://www.otago.ac.nz/otagobulletin/news/otago644919.html.

Urry, J. (2003). Social networks, travel and talk. The British Journal of Sociology, 54(2), 155-175. https://doi.org/10.1080/0007131032000080186

Urry, J. (2010). Consuming the planet to excess. Theory, Culture \& Society, 27(2-3), 191-212. https://doi.org/10.1177/0263276409355999

Whitmarsh, L., Capstick, S., Moore, I., Köhler, J., \& Le Quéré, C. (2020). Use of aviation by climate change researchers: Structural influences, personal attitudes, and information provision. Global Environmental Change, 65, 102184. https://doi.org/10.1016/j.gloenvcha.2020.102184

Wittel, A. (2001). Toward a network sociality. Theory, Culture \& Society, 18(6), 51-76. https://doi.org/10.1177/026327601018006003

Wynes, S., Donner, S. D., Tannason, S., \& Nabors, N. (2019). Academic air travel has a limited influence on professional success. Journal of Cleaner Production, 226, 959-967. https://doi.org/10.1016/j.jclepro.2019.04.109

Young, M., Markham, F., Reis, A. C., \& Higham, J. E. S. (2015). Flights of fantasy: A reformulation of the flyers' dilemma. Annals of Tourism Research, 54, 1-15. https://doi.org/10.1016/j.annals.2015.05.015 
Open Access This chapter is licensed under the terms of the Creative Commons Attribution 4.0 International License (http://creativecommons.org/licenses/ by/4.0/), which permits use, sharing, adaptation, distribution and reproduction in any medium or format, as long as you give appropriate credit to the original author(s) and the source, provide a link to the Creative Commons licence and indicate if changes were made.

The images or other third party material in this chapter are included in the chapter's Creative Commons licence, unless indicated otherwise in a credit line to the material. If material is not included in the chapter's Creative Commons licence and your intended use is not permitted by statutory regulation or exceeds the permitted use, you will need to obtain permission directly from the copyright holder.

(c) $\underset{8 \mathrm{BY}}{(1)}$ 